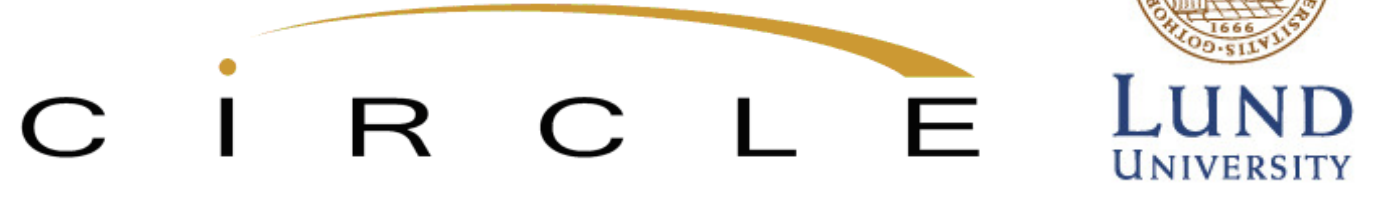

\title{
Survival of Entrepreneurial Firms: The Role of Agglomeration Externalities
}

\author{
Sam Tavassoli (Sam.Tavassoli@rmit.edu.au) \\ CIRCLE, Lund University, Sweden \& Royal Melbourne Institute of Technology, Australia \\ Viroj Jienwatcharamongkhol (Viroj.J@nek.lu.se) \\ Department of Economics, Lund University, Sweden
}

\section{Papers in Innovation Studies}

Paper no. 2016/28

This is a pre-print version of a paper that has been submitted for publication to a journal.

This version: October 2016

Centre for Innovation, Research and Competence in the Learning Economy (CIRCLE)

Lund University

P.O. Box 117, Sölvegatan 16, S-221 00 Lund, SWEDEN

http://www.circle.lu.se/publications 
WP 2016/28

\section{Survival of Entrepreneurial Firms: The Role of Agglomeration Externalities}

Sam Tavassoli, Viroj Jienwatcharamongkhol

Abstract: This paper analyzes the role of various types of agglomeration externalities on the survival rate of entrepreneurial firms. In particular, we trace the population cohort of newly-established and self-employed Swedish firms in the Knowledge-Intensive Business Service (KIBS) sector in 1997 up to 2012 and investigate the role of Marshallian and Jacobian externalities on the survival of these firms. We find that only Jacobian externalities (diversity) is positively associated with the survival of entrepreneurial firms. Not all Jacobian externalities matter though. Only the higher the "related variety" of the region in which an entrepreneurial firm is founded, the higher will be the survival chance of the firm, while "unrelated variety" barely has any significant correlation. The result is robust after controlling for extensive firm characteristics and individual characteristics of the founders. The main message here is: for a newly-established entrepreneurial firm, not only it matters who you are, but also where you are.

Keywords: Entrepreneurial firms; region; agglomeration externalities; survival analysis; related variety; unrelated variety

JEL: L26; J24; R12

Disclaimer: The authors are fully and solely responsible for the content of this working paper which does not necessarily represent the opinion of CIRCLE. 


\title{
Survival of Entrepreneurial Firms: The Role of Agglomeration Externalities
}

\author{
Sam Tavassoli $^{\mathrm{a}, \mathrm{b}}$ and Viroj Jienwatcharamongkhol ${ }^{\mathrm{c}}$ \\ ${ }^{\text {a }}$ Centre for Innovation, Research and Competence in the Learning Economy (CIRCLE), Lund University, Lund, Sweden \\ ${ }^{\mathrm{b}}$ School of Management, Royal Melbourne Institute of Technology (RMIT), Melbourne, Australia \\ Email: Sam.Tavassoli@rmit.edu.au \\ ${ }^{\mathrm{c}}$ Department of Economics, Lund University, Lund, Sweden \\ E-mail: Viroj.J@nek.lu.se
}

\begin{abstract}
This paper analyzes the role of various types of agglomeration externalities on the survival rate of entrepreneurial firms. In particular, we trace the population cohort of newlyestablished and self-employed Swedish firms in the Knowledge-Intensive Business Service (KIBS) sector in 1997 up to 2012 and investigate the role of Marshallian and Jacobian externalities on the survival of these firms. We find that only Jacobian externalities (diversity) is positively associated with the survival of entrepreneurial firms. Not all Jacobian externalities matter though. Only the higher the "related variety" of the region in which an entrepreneurial firm is founded, the higher will be the survival chance of the firm, while "unrelated variety" barely has any significant correlation. The result is robust after controlling for extensive firm characteristics and individual characteristics of the founders. The main message here is: for a newly-established entrepreneurial firm, not only it matters who you are, but also where you are.
\end{abstract}

Keywords: Entrepreneurial firms, region, agglomeration externalities, survival analysis, related variety, unrelated variety

JEL classifications: L26, J24, R12 


\section{Introduction}

There is an extensive literature on the role of individual attributes, skills, and motives of entrepreneurs on various measures of their success (Miner et al, 1992; Ray, 1993; Frank et al, 2007; Parker, 2009). But entrepreneurs establish firms and firms are located in the regions. The point of departure in this paper is that regions do differ with each other in terms of providing the supply of factors that enhance the survival (and growth) of these firms. One of the main factors that a region may provide is externalities and knowledge spillover that occur between firms within a region. Indeed there are evidences suggesting that the more knowledge spillover in the region, the more learning opportunities, hence the more innovation happens in the region (Feldman 1994; Anselin et al. 1997; Tavassoli and Carbonara 2014; Castaldi et al. 2014) ${ }^{1}$. Moreover, there are also ample evidences on the role of geography on the survival of entrepreneurial firms (Audretsch and Lehmann, 2005; Delgado et al, 2010). However, the extant studies rarely operationalized the fundamental theoretical building blocks of agglomeration externalities, especially when it comes to analyze the effect of agglomeration externalities on the performance of newly established entrepreneurial firms. A better understanding of the factors enhancing the survival rate of the newly established entrepreneurial firms is an important issue to investigate because these firms comprises a significant share of firms in terms of number and they might be the engine of growth in the economy (Schumpeter 1934), but their lives are relatively short.

Looking more specifically at studies concerning survival analysis of (entrepreneurial) firms, most of them have neglected the role of region until recently (this will be reviewed in Section 2). Among the few studies that take into account the role of region (Fotopoulos and Louri 2000; Fritch et al. 2006; Falck 2007; Wennberg and Lindqvist 2010), several gaps can be identified: First, these studies rarely distinguish between various types of agglomeration externalities (an exception is Neffke et al. (2012)) ${ }^{2}$. This is however an important issue because various agglomeration externalities are the fundamental theoretical building blocks of the geography and they have various sources and consequences (Rosenthal and Strange 2004). Second, there are no studies focusing particularly on entrepreneurial firms. This is again an

\footnotetext{
${ }^{1}$ This highlights the role of geography for innovation of firms, in so-called "geography of innovation" as a field of study (Feldman and Kogler 2010).

${ }^{2}$ Neffke et al. (2012) does not study the very small firms, although majority of firms in the economy are actually very small. We precisely focused on such sample size in this paper.
} 
important issue because entrepreneurial firms are the engine of growth in the economy. Third, the lack of individual-level data prevents most of previous studies from controlling for individual characteristics of the founder of the firms. This is vital to consider, particularly for newly founded firms, because entrepreneurs themselves are the firms' main capacity and constraint in these types of firms (Brown \& Kirchhoff, 1997).

The aim of this paper is to empirically analyze the role of various types of agglomeration externalities on the survival rate of entrepreneurial firms, by operationalizing and distinguishing between fundamental theoretical building blocks of agglomeration externalities. In order to do so, we focused on the population cohort of the newly-established self-employed Swedish firms in Knowledge Intensive Business Service (KIBS) sector in 1997. We track the life of these firms up to their death or maximum up to 2012 and performed the survival analysis, while controlling for extensive firm-level characteristics of firms and individual-level characteristics of the founders of these firms. We find that it does matter "where" the founders establish their firms (reflected in our agglomeration externalities variables). But not all agglomeration externalities are positively associated with the survival of entrepreneurial firms. It is only Jacobs' externalities (diversity) that matters. In particular, the higher the related variety of the region in which an entrepreneurial firm is founded, the higher will be the survival chance of the firm.

Overall, this paper contributes to both the literature in geography of innovation and entrepreneurship (by having a disaggregate unit of analysis down into the nano-level selfemployed firms and also proving systematic evidence on the role of region for entrepreneurial firms) and also it contributes to the literature in survival analysis of firms (by incorporating the role of region) ${ }^{3}$. In particular, the contribution of the paper is as follows: (i) we distinguish between the effects of various building blocks of agglomeration externalities on survival of firms (ii) our analysis traces the life and death of the "population" of entrepreneurial firms over a long period of time in all regions of an economy, and (iii) we are able to control for extensive firm-characteristics as well as individual-characteristics of the founders of the firms.

3 On the other hand, looking at the literature on geography (of innovation and entrepreneurship), the firm or entrepreneur as the unit of analysis is underdeveloped (Feldman 1994; Acs and Varga 2005). When the focus is on entrepreneurial individual or firm, usually the evidences are based on case study of a particular region and systematic evidence is still lacking (Fredin, 2014). 
The rest of the paper is organized as follows. Section 2 discusses how the literature explains the survival of firms and develops hypotheses concerning the role of various agglomeration externalities on the survival. Data and estimation strategy is presented in Sections 3 and 4. Section 5 presents the results of the empirical analysis. The paper concludes in Section 6 and offers suggestions for future research.

\section{Conceptual framework and hypotheses}

Survival analysis of firms has been the topic of interest in several literatures. First, the literature in industrial dynamics has extensively investigated the factors determining the survival of firms. Special attention is paid to the age and size of the firms (Audretsch and Mahmood 1995), the entry time of firms in terms of pre- or post-dominant design (Suarez and Utterback 1995; Klepper 2002), the characteristics of the industry and the stages of the industry life cycle (Fritsch et al. 2006), and pre-entry experience of firms (Klepper 2002). Second, the Resource-Based View considers profit as "the criteria of natural selection," where highly-performing firms survive and poor performance leads to its eventual surmise (Penrose (1952). Here the main determinant of survival of firm is the internal characteristics of firms. And finally, in evolutionary economic framework (Nelson and Winter, 1982; Klepper, 2002), and in particular in evolutionary economic geography analysis (Essletzbichler and Rigby 2010), the survival analysis of agents (e.g. firms) is considered as the "second moment". While the "first moment" in the analysis is to investigate the effect of plant location on the "creation" of variety (e.g. establishment of entrepreneurial firms), the "second moment" of the analysis is then to investigate the "survival" of firms by tracing their life. This less studied "second moment" entails linking the characteristics of agents with the broader environment in which they operate, e.g. regional factors (Essletzbichler and Rigby 2010).

Overall, there are less survival analysis studies that incorporate the effect of "region" (i.e. the business environment that a firm is born and try to survive). This area needs further investigation, as new evidence suggests that regional-level characteristics are the most important determinants of survival of firms, even more important than the conventional firmcharacteristics (Falck 2007). Among the few existing studies in this vein, most of them, however, consider agglomeration externalities as equivalent as the pure size of the regions (Fotopoulos and Louri 2000; Fritch et al. 2006; Falck 2007; Brixy and Grotz; 2007). There are 
very few studies that incorporate various types of agglomeration externalities in the survival analysis of firms (Neffke et al. (2012) is an exception), particularly entrepreneurial firms.

It is indeed important to incorporate the effect of the region, in which the entrepreneurial firm is established, on the survival rate of the entrepreneurial firms (Stephan 2011). The logic is as follows: various knowledge inputs are crucial for entrepreneurial firms. Such knowledge inputs can be generated internally within the firm and/or it can be brought into the firm externally through knowledge spillover mechanisms (Tavassoli et al, 2016). Previous studies show that such external knowledge is heavily comes from the very same region that the firm is located (Andersson and Karlsson 2007). This is because: (i) entrepreneurial activities are a complex process which entails exploration of tacit knowledge (Polanyi 1967) and (ii) such exploration of tacit knowledge is shown to be facilitated by the face-to-face interaction of economic agents in the same region (Storper and Venables 2004; Rodríguez-Pose and Crescenzi 2008). Moreover, the regions not only provide 'externalities' and knowledge spillovers, but also localized market-mediated mechanisms (e.g. input-output, labor market pooling etc.) might be equally important for the survival of newly established firms (Marshall, 1920). Apart from knowledge spillovers and localized market-mediated mechanism, other territorial 'socio-economic' and institutional factors can influence the performance of local entrepreneurial firms. These factors are in principle 'social filters' that are structural regional characteristics that would make a region more 'innovation prone', including: (i) education (ii) life-long learning (iii) sectoral composition, (iv) use of resources, and (v) Demographics (Crescenzi, Rodriguez-Pose and Storper, 2007). Such social filter may also influence the effect of various types of agglomeration externalities.

The importance of regions as the source of knowledge creation was perhaps recognized explicitly when scholars observed that innovation activities are clustered geographically in space, even more than production activities (Feldman 1994; Audretsch and Feldman 2004). Such recognition subsequently shaped a subfield in economic geography, the so-called "geography of innovation" (Feldman and Kogler 2010). One particular steam of literature in this field addresses the effect of regional characteristics on innovation of regions (Acs and Varga 2005). A conventional way to reflect the effect of regions on the performance of (innovative) firms located on those regions is through various agglomeration externalities 
(Rosenthal and Strange 2004) ${ }^{4}$. The seminal study by Glaeser et al (1992) spurs the literature concerning the effect of various agglomeration externalities on the performance of regions and firms. A common way to identify the building blocks of agglomeration externalities are to distinguish between Marshallian and Jacobs' externalities.

\subsection{Marshallian externalities}

Marshallian externalities refer to the specialization of a region in a narrow set of industrial sectors. The underlying assumption in Marshallian externalities is that knowledge is predominantly industry-specific (Marshall, 1920). Therefore firms may benefit from intraindustry knowledge spillovers and this can only be supported by concentration of a particular industry in a region. According to the "nursery cities" model, specialized cities play a larger role in exploitation of existing technologies, mostly carried out by larger firms seeking for low cost environments for mass-production (Duranton and Puga 2001). Therefore, strong specialized cities may not act as a desirable incubator for small and entrepreneurial firms, operating in service sectors, for at least three reasons: first, the activities of these firms are mainly exploration of new ideas and technologies and this is in contrast with what specialized cities usually offer (Leone and Struyk, 1976; Duranton and Puga 2001). Second, small and entrepreneurial firms in business service are heavily characterized by labor-intensive rather than capital-intensive, and therefore may enjoy less from a low cost environments for massproduction that specialized cities offer. Third, specialized regions may also intensify the competition between local plants, which can positively affect the exit rates of the local entrepreneurial firms, especially the fragile self-employed start-ups (Melitz and Ottaviano 2008). Indeed recent empirical evidence shows that specialization negatively affect the survival rates of newly established firms in the service sector of the U.S. economy (Acs, Armington, and Zhang, 2007). Fritch et al (2006) found the same negative effect, through competition mechanism, on the survival of newly founded German firms. Raspe and van Oort (2011) found the same negative effect for Dutch firms. Furthermore, Weterings and Marsili (2012) find that while specialization increases the survival rate of Dutch manufacturing firms, it has the negative effect particularly on KIBS firms.

\footnotetext{
${ }^{4}$ Agglomeration externalities are costs or benefits that firms gain by being located in geographical proximity of other economic agents.
} 
To sum up, specialized cities play a large role in exploitation of existing technologies, mostly carried out by larger firms seeking for low cost environments for mass-production ${ }^{5}$. This may not be a favorable place for a fragile, newly-established, and labor-intensive entrepreneurial firm in KIBS sector, which is rather looking for exploration of new ideas. Moreover, congestions effects and competition in specialized regions also harms the survival of these firms. Above discussion leads to our first hypothesis:

HP1: Marshallian externalities has a negative association with the survival rate of entrepreneurial firms.

\subsection{Jacobs' externalities}

Jacobs' externalities arise when firms benefit from inter-industry knowledge spillover, which occurs in diversified cities or regions (Glaeser et al. 1992). An essential part of Jacobs' externalities concerns the key role of the diversified cities in fostering knowledge spillover, innovation, and hence success of firms to survive and strive (Jacobs 1969; Anselin et al. 1997) ${ }^{6}$. Duranton and Puga (2001) provide the micro-foundation for such argument in their so-called "nursery cities" model. They show that an advantage of diversified cities is that firms can imitate several different processes without costly relocation. In other words, firms benefit from Jacobs' externalities because industrial diversity in the region lowers the search costs for new technologies. Therefore, firms prefer to perform their exploration activities in these cities, which in turn lead to innovation and hence survival of firms.

Accordingly, at the level of industries, Henderson et al (1995) found that high level of past industrial diversity increases the probability that a city will attract a high-tech new industry in the U.S. This indicates the role of Jacobs' externalities to create a favorable environment for new high-tech industries. Similarly, Neffke et al (2011) found that the effects of Jacobs' externalities are positive only for young industries in Sweden. Acs et al. (2007) found that city diversity is an important factor for survival of new firms. This is because in diversified and denser cities, entrepreneurs (founders of entrepreneurial firms) can have better access to tacit knowledge, obtain social ties, and build self-confidence (Sorenson and Audia, 2000). More interestingly, at the level of plant, Neffke et al (2012) found that Jacobs' externalities only contribute to the survival of Swedish plants in the first 15 years of their existence. While this

\footnotetext{
${ }^{5}$ This is in line with routine regime (Winter, 1984).

${ }^{6}$ As Jane Jacob argued, many innovations are the result of "adding new work to old ones".
} 
finding is obtained using all manufacturing firms (plants), it makes sense to expect the similar evidence, particularly for entrepreneurial firms, since nursery cities model is indeed about entrepreneurial firms. In addition, it is argued that to facilitate the inter-industry knowledge spillovers, there needs to be some sort of cognitive proximity or complementarity between these industries (within a region), thus leading to higher learning opportunities and innovation among the firms belonging to these industries (Nooteboom 2000). The complementarity aspect is particularly important for innovation, as far as knowledge is drawn from a variety of sectors, as in "recombinant innovation" (Weitzman 1998). In this line of query, an important contribution has been a distinction between related and unrelated variety of technological knowledge, where related variety measures the extent to which the knowledge and skill base of two industries overlap and unrelated variety measures the otherwise in a given region (Frenken et al, 2007). It is shown that the higher related variety of the region, the higher the (incremental) innovation (Tavassoli and Carbonara 2014; Castaldi et al. 2014). This is because a region with higher related variety can enjoy the higher learning opportunity and higher possibility of combining different ideas through inter-industry knowledge spillovers (Ejermo 2005; Frenken et al. 2007). This should be particularly the case for newly established firms. This is because: (i) smaller firms are more dependent on their environment and externalities in general (Fotopoulos and Louri 2000; Henderson 2003) and (ii) smaller firms usually have lower internal resources, such as human capital, in order to overcome a large cognitive distance existed in a region characterized by unrelated variety of knowledge (Cohen and Levinthal 1990). Therefore, these newly established firms should have an easier time to survive in a region characterized by higher related variety type of knowledge rather than the far-fetched unrelated variety type. Among the very few existing studies, Boschma and Wenting (2007) provide evidence that the survival of British automobile producers has been positively affected by the presence of local related industries such as bicycle producers. Moreover, according to the network success hypothesis (Brüderl and Preisendörfer, 1998), the networking activities of the founders is positively associated with their start-up's survival. The logic behind this hypothesis is the theory of socially embedded ties proposing that entrepreneurs can get financial and also non-financial (e.g. knowledge) resources cheaper through their networks than they could be obtained in the market. And considering the cognitive proximity argument, as discussed earlier, one could expect that the founders have easier time to network in a region that is characterized by higher related variety, and hence safeguard the higher chance of their survival. 
To sum up, according to the "nursery cities" model, diversified and specialized cities may coexist. The crucial point is that diversified cities act as nurseries (incubators) for new firms engaging in exploration of new technologies, leading to novel and entrepreneurial activities ${ }^{7}$. Therefore, we expect positive influence of Jacobs' externalities on survival rate of newly established (young) entrepreneurial firms. Above discussions lead to our second hypothesis:

HP2: Jacobs' externalities, particularly the related variety, has a positive association with the survival rate of entrepreneurial firms.

\section{Unit of analysis and Data}

\subsection{Unit of analysis}

It is important to clearly identify the unit of analysis particularly in studying entrepreneurship, since entrepreneurship is a multi-level phenomenon (Davidsson and Wiklund, 2001). The unit of analysis in this study is newly-established self-employed firms in the KIBS sector. We call these firms "entrepreneurial firms" in this study. The reason for such claim stems from a debate in the literature that most of self-employed firms are not really entrepreneurial in nature. Shane (2009) concluded that "a typical start-up is not innovative, creates few jobs, and generates little wealth". And "economic growth is about encouraging high quality, high growth companies to be founded, and it is not about starting a typical start-up". But it is often unclear "who" these potentially high quality, high-growth start-ups $\operatorname{are}^{8}$. Relying on technological regime literature (Malerba and Orsenigo, 1997), we argue that the 'sectoral affiliation' of a start-up can be an indication of the extent of innovation opportunities and hence the extent of potential high-growth for a start-up. This is indeed what Shane (2009) called it "entrepreneurial sector". Although not all KIBS firms are innovative (Delmar et al, 2011), KIBS still can be a good example for such "entrepreneurial sector" in Sweden. This is because of four reasons: (i) in KIBS sector, as of any knowledge-intensive sector, there are high innovation opportunities and there exists considerable uncertainty (which requires higher risk-taking from an entrepreneur), (ii) based on previous Swedish studies, KIBS sector startups have higher survival rate and have "better quality" in compare with other start-ups (Andersson et al, 2012; Ejermo \& Xiao, 2014), (iii) based on official data on observed high

\footnotetext{
${ }^{7}$ This is in line with entrepreneurial regime (Winter, 1984).

8 Similarly, Aldrich and Ruef (2006) made a distinction between reproducer and innovator start-ups and Samuelsson and Davidsson (2009) made a distinction between imitator and innovator start-ups. But again, it is not always clear who these innovator start-ups are.
} 
growth and innovativeness of firms in KIBS sector in Sweden (Statistic Sweden, 2014) ${ }^{9}$, and (iv) based on the fact that KIBS firms are co-producer of innovation (Hertog, 2000). To sum up, our unit of analysis is not individual founders, nor just a typical self-employed firm. It is "entrepreneurial firm", due to sectoral affiliation of the start-ups in this study and the innovation opportunities which is inherent to this specific sector, which in turn increases the chance that an individual entrepreneur not only discover (Kirzner, 1978) but also create opportunities (Schumpeter, 1934), i.e. establish an entrepreneurial firm ${ }^{10}$.

\subsection{Data}

The dataset comes from Firm and Establishment Dynamics database as well as longitudinal individual level database, both are provided by Statistics Sweden ${ }^{11}$. The coverage is the population of firms over a fifteen years period from 1997 to $2012^{12}$. We constructed our final dataset in the following steps. First, we started by identifying the newly established selfemployed firms in the KIBS sector in $1997^{13}$. Second, we matched these firms to those individuals who are classified as "entrepreneurs" in the individual-level dataset ${ }^{14}$. An entrepreneur who is matched with a corresponding self-employed firm should be the founder of that firm. Lastly, we matched these firms (together with their founders) with the regions that they have been established. Matching an entrepreneurial firm with its individual founder provides information on various individual characteristics of the founders, including the age, gender, income, education, and (possible) year of immigration into Sweden. Further matching

\footnotetext{
${ }^{9}$ KIBS is among the top innovative sectors in Sweden with over $60 \%$ of the firms engage in some forms of innovative activities (Statistic Sweden 2014). These innovating activities are: introducing product, process, marketing, and organization innovations as well as engaging in ongoing/abandoned product or process innovation.

${ }^{10}$ Focusing on KIBS sector allows us to go beyond the "wide" definition of entrepreneurship offered by Austrian school (Kirzner 1978) and focus on the Schumpeterian innovation-based definition of entrepreneurship (Landström 2007). The similar sectoral choice is preferred in previous Swedish survival analysis dealing with geography (Wennberg and Lindqvist 2010). Other recent Swedish studies also dealt with KIBS sector. Andersson and Hellerstedt (2009) used the total number of those individuals graduated in natural sciences, technology, and medicine over the period of 1994-2000. Delmar et al (2011) used all the firms in the knowledge-intensive industries from 1995-2002.

${ }^{11}$ Although there are other datasets to be used for identifying an entrepreneurial firm, such as Community Innovation Survey (CIS) or patent data (Tavassoli, 2015), none of these dataset offers a possibility of tracing newly established entrepreneurial firms over an extended period of time. Therefore we cannot use them in our survival analysis.

${ }^{12}$ Using the full population of firms based on high-quality and registered data, allow us to dramatically reduce problems related to inferences and internal validity, since our estimates are not based on a sample of firms.

${ }^{13}$ KIBS sectors are classified as two-digit European NACE codes 72-74. Moreover, 1997 is chosen since this is the earliest year that we can have the full set of control variables at the level of individual, firm, and region.

${ }^{14}$ The longitudinal individual level dataset provides information on various characteristics of each individual in Sweden. Among other things, it also classifies the main occupation type of each individual to be either (i) a sailor (ii) a farmer (iii) an employed (in public or private sectors) or (iv) an entrepreneur (founder of a business).
} 
with the region that firms are located paves the way to analyze the role of geography on survival of these entrepreneurial firms. We only kept those firms with a single founder, which accounts for 90 percentage of all newly established KIBS firms. We also kept only those firms which appear consecutively throughout the period until they disappear permanently in the dataset ${ }^{15}$. This procedures left us with total of 4682 firms (individual entrepreneurs). We track the formation of these firms and their possible shut-downs (exit) over time up to their death or maximum up to 2012.

\subsection{Geographical unit}

In order to investigate the conditional correlation between agglomeration externalities and survival of firms, first we need to define the geographical unit in which firms are located. Some studies used municipality as the geographical unit. However, particularly in the southern part of Sweden, sometimes municipalities are only small parts of metropolitan areas. This may cause the spatial autocorrelation problem in our analysis because, for instance, a municipality that is located at a short distance from the center of Stockholm should surely experience some of the agglomeration externalities that are generated there. ${ }^{16} \mathrm{We}$ instead use functional regions (Lokal Arbetsmarknad) because it is indeed shown in Sweden that knowledge flows transcend across municipality borders but are bound within functional regions (Andersson \& Karlsson, 2007). This is because knowledge production and access are found to differ systematically only across functional regions (Karlsson \& Johansson, 2006). This way we can internalize many spatial effects within the chosen geographical unit of analysis. We used the official classification which divides Sweden into 72 functional regions. In 1997, which is the year of establishment of the firms in our dataset, there are in total 4682 self-employed firms founded in the KIBS sector in Sweden. About half of these firms were founded in the three Swedish metropolitan areas, i.e. Stockholm, Gothenburg, and Malmö. Table A1 in the Appendix shows the distribution of these firms across the 72 functional regions.

\section{Estimation strategy and measurement}

\footnotetext{
${ }^{15}$ There is a small portion (about 1\%) of KIBS self-employed firms founded in 1997 that their founders moved out, while the firm continued to exist (i.e. "harvest sale" exit route (Wennberg et al, 2010)). Excluding this particular type of firms from our analysis did not change our main result.

${ }^{16}$ Those studies which used municipality as the geographic unit of analysis constructed their agglomeration externality indicators based on a number of geographical potentials (Neffke et al. 2012).
} 
We use survival analysis methodology in order to examine the exit of each firm in the study. This means that we study the time duration until an event, in this case the shut-down of firms, occurs. In particular, we utilize the semi-parametric Cox proportional hazards model as well as Parametric Survival Model. The main advantage of using the Cox model is that we do not need to specify the baseline model and hence avoid the potential arbitrary and incorrect model specification. The Cox model can still be estimated by the method of partial likelihood (Cox 1972). We use the Breslow method for handling ties. On the other hand, perhaps a disadvantage of the Cox model, which is semi-parametric in nature, is that the distribution of the survival time is unknown and the model is less consistent with the theoretical survival function. Therefore, we also employ the Parametric Survival Model as a robustness check. For this paper, we assume the commonly-used Weibull distribution, in which the hazard rate has a monotonic duration dependence, i.e. always decreasing over the study period ${ }^{17}$.

A general formulation of the hazard function can be written as:

$$
h(t)=h_{0}(t) \exp \left(\boldsymbol{X}_{A G G L} \boldsymbol{B}_{A G G L}+\boldsymbol{Z}_{1} \boldsymbol{B}_{Z 1}+\boldsymbol{Z}_{2} \boldsymbol{B}_{Z 2}+\boldsymbol{Z}_{3} \boldsymbol{B}_{Z 3}\right)
$$

where $h_{0}(t)$ is the time function of the hazard rate, which, in the case of Parametric Survival Model, follows Weibull distribution, i.e. $h_{0}(t)=\alpha t^{\alpha-1}$ ( $\alpha$ is the shape parameter that determines the duration dependence of the hazard function). In the case of semi-parametric Cox model, $h_{0}(t)$ is unspecified, which acts as the baseline hazard that captures the direct impact of firm's age on the survival of firm. $\boldsymbol{X}_{A G G L}$ is the vector of agglomeration externalities that are assumed to be associated with the survival of the entrepreneurial firms. The vector $\boldsymbol{X}_{A G G L}$ includes three agglomeration externalities variables, i.e. RelatedVariety and UnrelatedVariety (as Jacob's externalities) and Specialization (as Marshallian externalities). $Z_{1}, Z_{2}$, and $Z_{3}$ are the vectors of control variables, corresponding to individual-level, firmlevel, and other regional-level characteristics, respectively. $\boldsymbol{B}$ 's are the coefficients to estimate. The vector $\boldsymbol{Z}_{1}$ includes Age, Gender, Immigrant dummy, HighlyEducated dummy, and the number of firms that the founder of the entrepreneurial firm has been associated throughout the studied period (NrFirms). The vector $\boldsymbol{Z}_{2}$ includes the average growth rate of firm size (FirmSizeGrowth), dummies indicating whether a firm is founded through a spin-off

\footnotetext{
17 Assume the survival time $T$ follows a distribution with density function $f(t)=h(t) S(t)$, such that the survival function $S(t)=\int_{t}^{\infty} f(u) d u$, the commonly-used Weibull distribution implies that $S(t)=e^{-\lambda t^{\alpha}}$ and the hazard function $h(t)=\alpha t^{\alpha-1} \lambda$, where $\lambda$ denotes model parameters. On the contrary, the Cox model does not require a specification of the distribution, so $h(t)$ is simply $h_{0}(t) \lambda$, where $h_{0}(t)$ is the baseline hazard rate that corresponds to when parameters equal zero.
} 
from a parent company (Spinoff), or through a merger and acquisition (Merger). Finally, $\boldsymbol{Z}_{3}$ Controls for the size of the region by measuring the total employment within the functional region minus firm's employment (RegionSize $)^{18}$.

A conventional way of operationalizing the Jacob's externalities has been the usage of inverted Herfindahl Index. However, recent advancement suggest new ways of operationalization based on entropy measures (Frenken et al, 2007). The main advantageous of using entropy measure is that we can distinguish between two types of diversity within a region, i.e. within- and between- sector diversity. Such distinction has important implication because within-sector variety is the source of regional knowledge spillovers, while betweensector diversity is the source of a regional portfolio protecting from external shocks. Moreover, the decomposable nature of entropy means that diversity at several digit levels can be entered into a regression analysis without causing collinearity (Attaran, 1986). Following Frenken et al (2007), the RelatedVariety is constructed by calculating the weighted sum of entropy within the two-digit level industry codes in a given functional region:

$$
\begin{aligned}
\text { RelatedVariety } & =\sum_{g=1}^{G} P_{g} H_{g} \\
H_{g} & =\sum_{i \in S_{g}} \frac{p_{i}}{P_{g}} \log _{2}\left(\frac{1}{p_{i} / P_{g}}\right)
\end{aligned}
$$

where $P_{g}$ is a two-digit share of employment in a region which is calculated by the sum of five-digit shares $p_{i}: P_{g}=\sum_{i \in S_{g}} p_{i}$ assuming all five-digit industries $i$ fall under a same two-digit industry $S_{g}$. The idea is that all five-digit industries that fall within the same two-digit codes are technologically related and thus share a cognitive proximity, while at the same time each five-digit industry is still different from each other. Hence, the measure must be weighted by the varieties that are present within the two-digit codes. Since we are coving only KIBS firms in our survival analysis, we calculated the RelatedVariety using 2-digit and 5-digit employment only in the KIBS sector (and not the whole employment in all sectors in a region), in order to rule out the effect of unrelated sectors, when calculating the RelatedVariety for firms in the KIBS sector.

\footnotetext{
${ }^{18}$ Since the firm's employment in our study is always 1 in the beginning of the period (1997), value is far bigger than all of the other variables. We then decide to use the logged value. We also used population density as an alternative measure of the size of the region. Main results are very similar.
} 
On the other hand, UnrelatedVariety captures the extent of unrelated knowledge within a region and it is simply calculated as the entropy at the two-digit level:

$$
\text { UnrelatedVariety }=\sum_{g=1}^{G} P_{g} \log _{2}\left(\frac{1}{P_{g}}\right)
$$

Unlike RelatedVariety, when it comes to calculating the UnrelatedVariety, we use employment data for all sectors in a region, in order to allow for inter-sectoral knowledge spillover between unrelated sectors ${ }^{19}$.

The last variable Marshallian externalities or Specialization is an index of the conventional location quotient that captures the extent of spatial knowledge spillover of firms within the very same industry in a given region (Antonietti and Cainelli 2011):

$$
\text { Specialization }=\frac{P_{g}}{L_{g} / L}
$$

where $P_{g}$ is, as above, a two-digit share of employment in the industry code $g$ in a region, $L_{g}$ is the aggregate of the sectoral employment $g$ in the country, and $L$ is an aggregate national employment. The detail descriptions of all variables are presented in Table 1.

\section{[Table 1 about here]}

Here we would like to point out two technical points about our empirical strategy. First, an important assumption of the Cox model is that the effect of covariates is the same for firms of all ages. We think this assumption holds in our study because there is no evidence showing that individual characteristics have varying effects on the survival of firms over various ages, i.e. being time-dependent covariates. For instance, the effect of being a male entrepreneur on the survival of the firm should be the same in the year of establishment and five years later. There is, however, evidence showing that agglomeration externalities are time-dependent covariates (Neffke et al. 2012). Nevertheless, it is shown in Sweden that the agglomeration externalities variables start to show varying effects after 15 years of survival of the firms (plants) (Neffke et al. 2012). Since our time span is exactly fifteen years, our study should not experience the time-dependent effect of agglomeration externalities. Therefore, the assumption of time-independent covariates should hold in our study.

\footnotetext{
${ }^{19}$ Calculating UnrelatedVariety which is limited to only KIBS sectors (i.e. same fashion as calculating RelatedVariety) did not change our main results.
} 
Second, previous studies of agglomeration effects on firm survival distinguished between various types of exit: (i) exit by closure, (ii) exit by merger with others, and (iii) exit by acquisition by others (Globerman et al. 2005; Wennberg and Lindqvist 2010). While exit by closure (termination) is generally a negative outcome, merger or acquisition is not really a sign of failure. In contrast, divesting of their equity share can be seen as the success for entrepreneurs. Nevertheless, they are still in the risk of shut-down before the merger \& acquisition happens and hence contribute to the risk set up until the event. Therefore, treating all exits indiscriminately may bias our result. Therefore, we have kept in our analysis only those exits that are due to the "exit by closure" 20.

The correlation table is displayed below in Table 2. Generally, there is no high correlation among all pairs of variables, so multicollinearity is less likely to cause a problem in the analysis. An exception is between some of agglomeration externalities variable, which is expected. As Duranton and Puga (2001) noted, diversified, specialized, and large cities may co-exist. Nevertheless, we also run the survival analysis with each of these variables separately (reported in the next section) and can conclude that multicollinearity does not cause a problem in our interpretation of the result. Descriptive statistics are displayed in Table A2 in the Appendix.

\section{[Table 2 about here]}

\section{Results}

We first list the number and rate of surviving firms during the fifteen years period of the study in Table 3. These are the estimates based on non-parametric Kaplan-Meier survival estimate. About $61 \%$ of firms survive up to 5 years after their establishment and about $42 \%$ of firms survive up to 10 years. At the end of the study period, $27 \%$ of firms survived.

\section{[Table 3 about here]}

\footnotetext{
20 And alternative strategy would be to estimate competing risks models, which would have allowed us to separate all possible exits, as separate events. Unfortunately, we cannot identify and distinguish all possible types of exits in our dataset in order to perform a proper competing risks models. For instance, we are not able to properly identify the death of a founder or when a founder migrate abroad. Since a founder is strictly attached to his/her firms in our empirical setting (except 1\% of the founders that moved out of his/her firm and the firm still continued to exist), a death or migration of the founder means exit of his/her firm in our dataset. Therefore, we are not able to identify at least two exit events (at firm-level outcome). This issue indeed makes us hesitant to go for competing risks models.
} 
Next, we report the coefficient estimates of agglomeration externalities variables (and other control variables) in Table 4. In this table, Model (1) to (4) are based on Semi-Parametric Cox proportional hazard model and Model (5) to (8) are based on Parametric Survival Models with Weibull survival distribution (the discussion of choosing these models were presented earlier in the Section 4). In order to avoid the issues concerning a potential multicollinearity between our agglomeration externalities variables, we insert them one-by-one in Model (1) to (3) (also Model (5) to (7)). Then Model (4) and (8) are the full models, which also control for individual-characteristics of the founders, firm-characteristics, and other regional characteristics.

\section{[Table 4 about here]}

The significant coefficients of a discrete variable can be interpreted that the hazard of having the status in one group (e.g. female) is relatively different from the hazard of another group (male). The positive numbers imply a higher rate of firm exit compared to the referenced group, and vice versa. The same applies for an increase in continuous variables, i.e. it suggests a higher chance in firm exit. To put it differently in terms of firm's survival, we can say that a negative coefficient of a variable means that the variable is correlated with the survival of the firms positively, and vice versa.

Results based on Semi-Parametric Cox model and Parametric Survival Model are very similar to each other. Starting from Jacobs's externalities, both RelatedVariety and UnrelatedVariety in the region are positively correlated with the survival of the firms. This is in line with the "nursery cities" model, in which diversified cities act as nurseries (incubators) for new firms engaging in exploration of new technologies, leading to novel and entrepreneurial activities. However, when it comes to the composition of the diversity in the region, it turns out that it is only the related variety of knowledge that is significantly correlated with the survival. On the other hand, unrelated variety of knowledge does not really matter for survival of firms, as it is barely significant. This means entrepreneurial firms can benefit from inter-industry knowledge spillover, but that spillover comes from other firms operating in related industries and not from industries that are too far in terms of cognitive distance. 
Marshallian externalities (Specialization) shows a negative association with the firm survival in the both models (3) and (7). This result can be explained again by "nursery cities" model: specialized regions may not act as a desirable incubator for small and entrepreneurial firms, operating in business service sectors. This is because the activities of these firms are mainly exploration of new ideas and technologies and this is in contrast with what specialized cities usually offers, i.e. exploitation of existing technologies, mostly carried out by larger firms seeking for low-cost environment for a mass production base. Moreover, specialized regions can harm the survival of the newly established service firms through congestion costs and fierce competition between newly arrived and incumbent firms. This is in line with results of previous studies (Acs et al, 2007; Weterings and Marsili 2012). However, unlike previous studies, the effect of Marshallian externalities is not significant in our study.

In model (4) and (8), we control for individual- , firm-, and other regional- characteristics and the results concerning the association between agglomeration externalities and survival in the earlier models still hold. This shows there is a conditional positive correlation between related variety and survival. Moreover, considering our control variables in these two models, we observe several interesting results. First, older entrepreneurs (Age) are associated with lower chance of survival. One explanation might be that older entrepreneurs are more risk averse and do not keep up with the changing business environment so their previous experiences are not applicable, which may result in an earlier exit. Second, being a male entrepreneur (Gender) is associated with a higher chance of exit. Similarly, Giannetti and Simonov (2004) analyzed entrepreneurship in Sweden and find that males tend to abandon entrepreneurial activities sooner in compare with females. The results in other studies are inconclusive ${ }^{21}$. Third, having at least three years of university education (HighlyEducated) is also associated with a higher chance of survival. Although a crude measure, higher education is usually perceived as a main source of human capital. Previous studies also have shown that higher education is often associated with successful start-ups (Chandler \& Hanks, 1994; Evans \& Leighton, 1990; Holtz-Eakin, Rosen, \& Weathers, 2000). Fourth, the more number of 'other' firms the founder of a firm is engaged to during the period 1997-2012, either establishing a new firm or working as an employee (NrFirms), the lower chance of the survival for the focal firm. This makes sense because in such situation, the founder would have less time and

\footnotetext{
${ }^{21}$ Various studies find that male entrepreneurs lead firms that stay in business longer than female counterpart (Taylor, 1999, among other). On the other hand, Watson (2012) finds that there is little difference in networking between male- and female-controlled Australian SMEs after controlling for size, education, industry and size.
} 
dedication to allocate for the focal firm, i.e. less commitment from the entrepreneur. Fifth, and turning to the firm-level control variables, being a spin-off start up is positively associated with higher survival rate. This is due to the possible support that a spin-off start-up may receive from the parents company, both in terms of knowledge and physical resources (Andersson and Klepper, 2013). All in all, the results in Table 4 show that hypothesis 1 concerning Marshallian externalities is rejected, while hypothesis 2 concerning Jacobian externalities is confirmed.

\section{Conclusion}

This paper aimed to analyze the association between various building blocks of agglomeration externalities and survival of entrepreneurial firms. In order to do so, we focus on the population of Swedish KIBS firms that are founded by entrepreneurs in 1997. We trace the life of these firms up to their death or maximum up to 2012. Using the semi-parametric and parametric survival models, we find the followings: First, not all agglomeration externalities enhance the survival chance of entrepreneurial firms. Second, it is only Jacobs' externalities (diversity) in the region that is positively and significantly associated with the survival rate of entrepreneurial firms. This means being in a diverse area can benefit new firms by offering a greater exposure of new ideas and management practices that may complement firm's knowledge to innovate and help them survive. Third, not all types of diversity in the region are associated with the survival of entrepreneurial firms though. It is the related variety of knowledge in the region that matters. This is because young entrepreneurial firms usually have lower internal resources, such as human capital, in order to overcome the large cognitive distance existed in a region characterized by unrelated variety of knowledge (Cohen and Levinthal, 1990). Therefore, these firms should have a greater chance to survive in a region characterized by higher related variety type of knowledge rather than the far-fetched unrelated variety type. Fourth, controlling for extensive sets of firm-characteristics as well as individual-characteristics of the entrepreneur, the same conclusions still hold. Therefore, for a newly-established entrepreneurial firm, not only it matters who you are, but also where you are (where you establish your company).

It is worthy to mention that our estimation strategy in this paper does not explicitly address potential endogeneity issues, which might occur from the 'reverse causality' as well as 'sorting' problem. First, there might be reverse causality of the agglomeration externalities variables being affected from firms' death in a region. However, we believe such endogeneity 
issue should not be severe, since the agglomeration variables do generally exhibit a stable tendency over time, so they should be affected by the dependent variable only slightly and hence the severity of the endogeneity problem should be rather marginal here. Second, there might be a sorting problem, since the 'best' performing firms (in terms of survival) do not choose their location randomly. Conversely, the best firms might self-select themselves into certain regions that possess certain characteristics (e.g. in terms of higher related variety profile of the region). However, again we believe such endogeneity issue should not be severe, because it is usually difficult for firms to detect the extent of agglomeration externalities (such as related variety) and base their location decision upon such detection (although detecting specialization is easier for firms). Nevertheless, the endogeneity issue, however small, still pose a limitation to our study and has prevented us to have causal interpretation.

There are some unique features of Swedish economy (related to entrepreneurial firms) which limits the generalizability of our results. Such features are: (i) being a small and open economy (ii) being a service-economy (about 70\% of GDP and also employment comes from service sector), (iii) Sweden's leading firms are, however, old and are predominantly concentrated in older capital-intensive industries (Andersson and Klepper 2013), and (iii) the specific geographical landscape of the economy with three metropolitan areas (Stockholm, Gothenburg and Malmö), which is associated with the concentration of the half of the entrepreneurial firms in the country.

There are several suggestions for future studies. First, we construct our agglomeration externalities variables based on predefined functional regions. An extension could be to apply a recently developed methodology using spatial micro-data to build the agglomeration externalities variable (Dubé and Brunelle 2014). Second, we have focused on self-employed entrepreneurial firms accounting for $90 \%$, which implies that we have dropped out the $10 \%$ of firms with more than one founder, which however could be the most high potential (teams) firms (Hellerstedt, 2009). Further studies particularly could focused on these entrepreneurial "teams". Third, we construct our agglomeration externalities variables (particularly Jacobs') based on sectoral composition of the regions. An alternative way is to construct them based on composition of the skill-based or occupation of the individual entrepreneurs (founder of business) in the region (Backman and Kohlhase 2013). Fourth, we focus on the role of intraregional externalities in this paper for the survival of firms, while leaving out inter-regional 
knowledge linkages. There are indeed good reasons to believe that newly established firms are highly dependent on their local environment and they are not large enough to establish external links (Fotopoulos and Louri 2000; Henderson 2003). Nevertheless, there are recent counter-argument pointing that knowledge intensive firms may get their knowledge through inter-regional linkages (Ponds et al, 2010). Investigation of the effect of such intra- vs. interregional linkages on survival of entrepreneurial firms can be an interesting topic of future studies. Lastly, our study focused on agglomeration economies as regional factors. There could be other regional factors that may affect the survival of entrepreneurial firms, such as local institutional factors, local demand factors, and existence of local social capital in favor of the individual entrepreneurs. Future studies are needed to investigate these other types of regional factors.

\section{Bibliography}

Acs, Z. J., \& Varga, A. (2005). Entrepreneurship, agglomeration and technological change. Small Business Economics, 24(3), 323-334.

Acs, Z. J., Armington, C., \& Zhang, T. (2007). The determinants of new-firm survival across regional economies: The role of human capital stock and knowledge spillover. Papers in Regional Science, 86(3), 367-391.

Aldrich, H., \& Ruef, M. (2006). Organizations Evolving. London: Sage.

Andersson, M., \& Hellerstedt, K. (2009). Location Attributes and Start-ups in Knowledge-Intensive Business Services. Industry and Innovation, 16(1), 103-121.

Andersson, M., \& Karlsson, C. (2007). Knowledge in Regional Economic Growth-The Role of Knowledge Accessibility . Industry \& Innovation, 14(2), 129-149.

Andersson, M., \& Klepper, S. (2013). Characteristics and performance of new firms and spinoffs in Sweden. Industrial and Corporate Change, 22(1), 245-280.

Andersson, M., Baltzopoulos, A., \& Lööf, H. (2012). R\&D strategies and entrepreneurial spawning. Research Policy,, 41(1), 54-68.

Anselin, L., Varga, A., \& Acs, Z. (1997). Local geographic spillovers between university research and high technology innovations. Journal of Urban Economics, 42, 422-448.

Antonietti, R., \& Cainelli, G. (2011). The role of spatial agglomeration in a structural model of innovation, productivity and export. Annals of Regional Science, 46, 577-600.

Attaran, M. (1986). Industrial diversity and economic performance in US areas. The Annals of Regional Studies, 20(2), 44-54.

Audretsch, D. B., \& Lehmann, E. E. (2005). Does the knowledge spillover theory of entrepreneurship hold for regions? Research Policy, 34(8), 1191-1202. 
Audretsch, D. B., \& Mahmood, T. (1995). New firm survival: new results using a hazard function. The Review of Economics and Statistics, 97-103.

Audretsch, D., \& Feldman, M. (2004). Knowledge Spillovers and the Geography of Innovation. In J. V. Henderson, \& J. Thisse, Handbook of Urban and Regional Economics: Cities and Geography, Volume 4 (pp. 2713-2739). Amsterdam: North Holland Publishing.

Backman, M., \& Kohlhase, J. (2013). The Influence of Diversity on the Formation, Survival and Growth of New Firms. Working Paper Series in Economics and Institutions of Innovation No.337.

Baum, J. A. (1996). Organizational ecology. Studying Organization: Theory and Method, 71-108.

Boschma, R. A., \& Wenting, R. (2007). The spatial evolution of the British automobile industry: Does location matter? Industrial and Corporate Change, 16, 213-38.

Brixy, U., \& Grotz, R. (2007). Regional patterns and determinants of birth and survival of new firms in Western Germany. Entrepreneurship and Regional Development, 19(4), 293-312.

Brown, T., \& Kirchhoff, B. (1997). Resource acquisition self-efficacy: Measuring entrepreneur's growth ambitions. Frontiers in entrepreneurship research, 59-60.

Brüderl, J., \& Preisendörfer, P. (1998). Network support and the success of newly founded business. Small business economics, 10(3), 213-225.

Castaldi, C., Frenken, K., \& Los, B. (2014). Related Variety, Unrelated Variety and Technological Breakthroughs: an analysis of US state-level patenting. Regional Studies. doi:10.1080/00343404.2014.940305

Cohen, W., \& Levinthal, D. (1990). Absorptive Capacity: A New Perspective on Learning and Innovation. Administrative science quarterly, 35(1), 128-152.

Cox, D. R. (1972). Regression Models and Life Tables (with Discussion). Journal of the Royal Statistical.

Crescenzi, R., Rodríguez-Pose, A., \& Storper, M. (2007). The territorial dynamics of innovation: a Europe-United States comparative analysis. Journal of Economic Geography, 7(6), 673-709.

Delgado, M., Porter, M. E., \& Stern, S. (2010). Clusters and entrepreneurship. Journal of Economic Geography, 10(4), 495-518.

Delmar, F., Wennberg, K., \& Hellerstedt, K. (2001). Endogenous growth through knowledge spillovers in entrepreneurship: an empirical test. Strategic Entrepreneurship Journal, 6(3), 199-226.

Dubé, J., \& Brunelle, C. (2014). Dots to dots: a general methodology to build local indicators using spatial micro-data. The Annals of Regional Science, 53(1), 245-272.

Duranton, G., \& Puga, D. (2001). Nursery cities: Urban diversity, process innovation, and the life cycle of products. American Economic Review , 1454-1477.

Ejermo, O. (2005). Technological Diversity and Jacobs' Externality Hypothesis Revisited. Growth and Change, 36(2), 167-195.

Ejermo, O., \& Xiao, J. (2014). Entrepreneurship and survival over the business cycle: how do new technology-based firms differ? Small Business Economics, 43(2), 411-426.

Essletzbichler, J., \& Rigby, D. L. (2010). Generalized Darwinism and evolutionary economic geography. In The handbook of evolutionary economic geography (pp. 43-61). 
Evans, D. S., \& Leighton, L. S. (1990). Small business formation by unemployed and employed workers. Small Business Economics, 2(4), 319-330.

Falck, O. (2007). Survival chances of new businesses: do regional conditions matter? Applied Economics, 39(16), 2039-2048.

Feldman, M. P. (1994). The geography of innovation. Dordrecht: Kluwer Academic.

Feldman, M. P., \& Kogler, D. F. (2010). Stylized Facts in the Geography of Innovation. In B. Hall, \& N. Rosenberg, Handbook of Economics of Technical Change. Oxford: Elsevier.

Fotopoulos, G., \& Louri, H. (2000). Location and survival of new entry . Small Business Economics, 14(4), 311-321.

Frank, H. L. (2007). The significance of personality in business start-up intentions, start-up realization and business success. Entrepreneurship \& Regional Development, 19(3), 227-251.

Fredin, S. (2014). The Dynamics and Evolution of Local Industries-The Case of Linköping, Sweden. European Planning Studies, 22(5), 929-948.

Fritsch, M., Brixy, U., \& Falck, O. (2006). The effect of industry, region, and time on new business survival-a multi-dimensional analysis. Review of industrial organization , 28(3), 285-306.

Giannetti, M., \& Simonov, A. (2004). On the determinants of entrepreneurial activity: Social norms, economic environment and individual characteristics. Swedish Economic Policy Review, 11(2), 269-313.

Gimeno, J., Folta, T. B., Cooper, A. C., \& Woo, C. Y. (1997). Survival of the fittest? Entrepreneurial human capital and the persistence of underperforming firms. Administrative science quarterly, 750-783.

Glaeser, E., Kallal, H., Scheinkman, J., \& Shleifer, A. (1992). Growth of cities. Journal of Political Economy, 100, 1126-1152.

Globerman, S., Shapiro, D., \& Vining, A. (2005). Clusters and intercluster spillovers: Their influence on the growth and survival of Canadian information technology firms. Industrial and Corporate Change, 14, 27-60.

Hellerstedt, K. (2009). The composition of new venture teams: Its dynamics and consequences. Doctoral Dissertation: Jönköping International Business School.

Henderson, J. V., Kuncoro, A., \& Turner, M. (1995). Industrial development in citie. Journalof Political Economy, 103, 1067-1090.

Henderson, V. J. (2003). Marshall's scale economics. Journal of Urban Economies, 53, 1-28.

Hertog, P. D. (2000). Knowledge-intensive business services as co-producers of innovation. International Journal of Innovation Management, 4(04), 491-528.

Holtz-Eakin, D., Rosen, H. S., \& Weathers, R. (2000). Horatio Alger meets the mobility tables. Small Business Economics, 14(4), 243-274.

Jacobs, J. (1969). The Economy of Cities. New York: Random House, Inc. 
Karlsson, C., \& Johansson, B. (2006). Dynamic and Entrepreneurship in a Knowledge-based Economy. In C. Karlsson, B. Johansson, \& R. Stough, Entrepreneurship and Dynamics in the Knowledge Economy (pp. 12-46). New York: Routledge.

Kirzner, I. M. (1978). Competition and Entrepreneurship. University of Chicago press.

Klepper, S. (2002). Firm survival and the evolution of oligopoly. RAND journal of Economics, 37-61.

Krugman, P. (1991). Geography and Trade. Cambridge MA: The MIT Press.

Landström, H. (2007). Pioneers in entrepreneurship and small business research. Vol. 8. Springer.

Leone, R. A., \& Struyk, R. (1976). The incubator hypothesis: evidence from five SMSAs. Urban Studies, 13(3), 325-331.

Malerba, F., \& Orsenigo, L. (1997). Technological Regimes and Sectoral Patterns of Innovative Activities. Industrial and corporate change, 6(1), 83-117.

Marshall, A. (1920). The Principles of Economics. London: McMillan.

Melitz, M. J., \& Ottaviano, G. I. (2008). Market size, trade, and productivity. The review of economic studies, 75(1), 295-316.

Miner, J. B., Smith, N. R., \& Bracker, J. S. (1992). Predicting firm survival from a aknowledge of entrepreneur task motivation. Entrepreneurship \& Regional Development, 4(2), 145-154.

Neffke, F. M., Henning, M., \& Boschma, R. (2012). The impact of aging and technological relatedness on agglomeration externalities: a survival analysis. Journal of Economic Geography, 12(2), 485-517.

Neffke, F., Svensson Henning, M., Boschma, R., Lundquist, K., \& Olander, L. (2011). The Dynamics of Agglomeration Externalities along the Life Cycle of Industries. Regional Studies, 45(1), 49-65.

Nelson, R. R., \& Winter, S. G. (1982). An Evolutionary Theory of Economic Change. Cambridge: Harvard University Press.

Nooteboom, B. (2000). Learning and innovation in organizations and economies. Oxford: Oxford University Press.

Parker, S. C. (2009). The economics of entrepreneurship. Cambridge University Press.

Penrose, E. (1956). The theory of the growth of the firm. Oxford: Oxford University Press.

Polanyi, M. (1967). The Tacit Dimension. London: Routledge and Kegan Paul.

Ponds, R., van Oort, F., \& Frenken, K. (2010). Innovation, spillovers and university-industry collaboration: an extended knowledge production function approach. Journal of Economic Geography, 10, 231-255.

Raspe, O., \& van Oort, F. (2011). Growth of new firms and spatially bounded knowledge externalities. The annals of regional science , 46(3), 495-518.

Ray, D. M. (1993). Understanding the entrepreneur: entrepreneurial attributes, experience and skills. Entrepreneurship \& Regional Development, 5(4), 345-358.

Rodríguez-Pose, A., \& Crescenzi, R. (2008). R\&D, spillovers, innovation systems and the genesis of regional growth in Europe. Regional Studies, 42(1), 51-67. 
Rosenthal, S. S., \& Strange, W. C. (2004). Evidence on the nature and sources of agglomeration economies. Handbook of regional and urban economics , 4, 2119-2171.

Samuelsson, M., \& Davidsson, P. (2009). Does venture opportunity variation matter? Investigating systematic process differences between innovative and imitative new ventures. Small Business Economics, 33(2), 229-255.

Schumpeter, J. A. (1934). The theory of economic development. Cambridge, Mass.: Hardvard University Press (1st edn. 1911).

Shane, S. (2009). Small Business Economics. Why encouraging more people to become entrepreneurs is bad public policy, 33(2), 141-149.

Sorenson, O., \& Audia, P. G. (2000). The Social Structure of Entrepreneurial Activity: Geographic Concentration of Footwear Production in the United States 1940-1989. American Journal of Sociology, 106(2), 424-462.

Statistic Sweden. (2014). Innovation activity in Swedish enterprises 2010-2012. Stockholm: Statistiska centralbyrån.

Stephan, A. (2011). Locational conditions and firm performance: introduction to the special issue. The annals of regional science, 46(3), 487-494.

Storper, M., \& Venables, A. (2004). Buzz: face-to-face contact and the urban economy. Journal of Economic Geography, 4, 351-370.

Suarez, F. F., \& Utterback, J. M. (1995). Dominant designs and the survival of firms. Strategic management journal, 16(6), 415-430.

Tavassoli, S. (2015). Innovation determinants over industry life cycle. Technological Forecasting and Social Change, 91, 18-32.

Tavassoli, S., \& Carbonara, N. (2014). The Role of Knowledge Variety and Intensity for Regional Innovative Capability. Small Business Economics, 43(2), 493-509.

Tavassoli, S., Bengtsson, L., \& Karlsson, C. (2016). International Entrepreneurship and Management Journal. doi:10.1007/s11365-016-0405-8

Taylor, M. P. (1999). Survival of the fittest? An analysis of self-employment duration in Britain. The Economic Journal, 109(454), 140-155.

Watson, J. (2012). Networking: Gender differences and the association with firm performance. International Small Business Journal, 30(5), 536-558.

Weitzman, M. L. (1998). Recombinant growth. Quarterly Journal of Economics , 331-360.

Wennberg, K., \& Lindqvist, G. (2010). The effect of clusters on the survival and performance of new firms. Small Business Economics, 34(3), 221-241.

Wennberg, K., Wiklund, J., DeTienne, D., \& Cardon, M. (2010). Reconceptualizing entrepreneurial exit: Divergent exit routes and their drivers. Journal of Business Venturing, 25(4), 361-375.

Weterings, A., \& Marsili, O. (2012). Spatial concentration of industries and new firm exits: Does this relationship differ between exits by closure and by M\&A? Regional Studies, 1-15. 
Winter, S. G. (1984). Schumpeterian Competition in Alternative Technological Regime. Journal of Economic Behavior and Organization, 5, 287-320. 


\begin{tabular}{|c|c|c|}
\hline Variables & Description & Source \\
\hline \multicolumn{3}{|c|}{ AGGLOMERATION EXTERNALITIES } \\
\hline RelatedVariety & $\begin{array}{l}\text { Weighted sum of entropy of total employment } \\
\text { within two-digit NACE codes of the functional } \\
\text { region in } 1997\end{array}$ & $\begin{array}{l}\text { Author's calculation, from Firms } \\
\text { and Establishments Dynamic } \\
\text { database, Statistics Sweden }\end{array}$ \\
\hline UnrelatedVariety & $\begin{array}{l}\text { Entropy of total employment within two-digit } \\
\text { codes of the functional region in } 1997\end{array}$ & $"$ \\
\hline Specialization & $\begin{array}{l}\text { Location quotient index of the functional region } \\
\text { in } 1997\end{array}$ & $"$ \\
\hline \multicolumn{3}{|c|}{$\begin{array}{l}\text { CONTROL VARIABLES } \\
\text { Regional characteristics }\end{array}$} \\
\hline RegionSize & $\begin{array}{l}\text { Total employment in the functional region where } \\
\text { the firm is located in } 1997\end{array}$ & $\begin{array}{l}\text { Author's calculation, from Firms } \\
\text { and Establishments Dynamic } \\
\text { database, Statistics Sweden }\end{array}$ \\
\hline \multicolumn{3}{|c|}{ Individual characteristics } \\
\hline Age & $\begin{array}{l}\text { Age of entrepreneur at time of setting up the firm } \\
\text { in } 1997\end{array}$ & $\begin{array}{l}\text { Individual database, Statistics } \\
\text { Sweden }\end{array}$ \\
\hline Gender & $\begin{array}{l}\text { A dummy indicating gender of the entrepreneur, } \\
\text { taking value of } 0 \text { for female and } 1 \text { for male }\end{array}$ & $"$ \\
\hline Immigrant & $\begin{array}{l}\text { A dummy taking value of } 1 \text { if the entrepreneur } \\
\text { has an immigrant background by moving into } \\
\text { Sweden from their countries of birth, } 0 \text { otherwise }\end{array}$ & $"$ \\
\hline HighlyEducated & $\begin{array}{l}\text { A dummy taking value of } 1 \text { if the entrepreneur } \\
\text { has at least three years of university education, } 0 \\
\text { otherwise }\end{array}$ & ” \\
\hline NrFirms & $\begin{array}{l}\text { The total number of firms that the entrepreneur is } \\
\text { associated with during } 1997 \text { and } 2012 \text {. }\end{array}$ & $"$ \\
\hline \multicolumn{3}{|c|}{ Firm characteristics } \\
\hline FirmSizeGrowth & $\begin{array}{l}\text { The average growth rate of total number of } \\
\text { employees during } 1997 \text { and } 2012 \text {. }\end{array}$ & $\begin{array}{l}\text { Firms and Establishments } \\
\text { Dynamic database, Statistics } \\
\text { Sweden }\end{array}$ \\
\hline Spin-off & $\begin{array}{l}\text { A dummy taking value of } 1 \text { if the firm is founded } \\
\text { from a division from another firm in 1997, } 0 \\
\text { otherwise }\end{array}$ & $"$ \\
\hline Merger & $\begin{array}{l}\text { A dummy taking value of } 1 \text { if the firm is founded } \\
\text { from a merger and acquisition in 1997, } 0 \\
\text { otherwise }\end{array}$ & $"$ \\
\hline
\end{tabular}


Table 2: Correlation matrix

\begin{tabular}{|c|c|c|c|c|c|c|c|c|c|c|c|c|}
\hline & RV & URV & Spec & Reg.Size & Nr.Firms & Age & Gender & Immig & HighEduc & EmpG & Spin-offs & Merger \\
\hline RelatedVariety & 1 & & & & & & & & & & & \\
\hline UnrelatedVariety & $0.421 * * *$ & 1 & & & & & & & & & & \\
\hline Specialization & $-0.099 * * *$ & $-0.232 * * *$ & 1 & & & & & & & & & \\
\hline NrFirms & 0.010 & 0.018 & $-0.034 *$ & 0.024 & 1 & & & & & & & \\
\hline Age & -0.027 & $-0.045^{* *}$ & 0.008 & $-0.071 * * *$ & $-0.419 * * *$ & 1 & & & & & & \\
\hline Gender & $0.036^{*}$ & $0.032 *$ & -0.000 & $0.047 * *$ & $0.056 * * *$ & $-0.106 * * *$ & 1 & & & & & \\
\hline Immigrant & $0.041 * *$ & $0.074 * * *$ & -0.011 & $0.073 * * *$ & -0.025 & 0.010 & 0.020 & 1 & & & & \\
\hline HighlyEducated & $0.037 *$ & $0.072 * * *$ & 0.009 & $0.078 * * *$ & $0.031 *$ & $0.039 * *$ & 0.005 & -0.001 & 1 & & & \\
\hline EmployGrowth & -0.020 & -0.009 & 0.008 & -0.024 & $0.030 *$ & $-0.040 * *$ & $-0.032 *$ & 0.004 & $-0.050 * * *$ & 1 & & \\
\hline Spin-offs & 0.013 & 0.007 & 0.016 & 0.010 & -0.011 & 0.018 & -0.013 & -0.008 & -0.017 & 0.012 & 1 & \\
\hline Merger & -0.022 & -0.028 & 0.025 & -0.022 & -0.015 & -0.024 & -0.005 & -0.014 & $-0.044 * *$ & -0.003 & -0.013 & 1 \\
\hline
\end{tabular}

$* \mathrm{p}<0.05, * * \mathrm{p}<0.01, * * * \mathrm{p}<0.001$ 
Table 3: Survival rate of KIBS firms, 1997-2012

\begin{tabular}{cccc}
\hline Year & Number of Firms & Number of Exit & Survival Rate \\
\hline 1 & 4617 & 648 & $86 \%$ \\
2 & 3969 & 379 & $78 \%$ \\
3 & 3590 & 342 & $70 \%$ \\
4 & 3248 & 229 & $65 \%$ \\
5 & 3019 & 223 & $61 \%$ \\
6 & 2796 & 250 & $55 \%$ \\
7 & 2546 & 168 & $52 \%$ \\
8 & 2378 & 153 & $48 \%$ \\
9 & 2225 & 152 & $45 \%$ \\
10 & 2073 & 147 & $42 \%$ \\
11 & 1926 & 142 & $39 \%$ \\
12 & 1784 & 158 & $35 \%$ \\
13 & 1626 & 193 & $31 \%$ \\
14 & 1433 & 208 & $27 \%$ \\
15 & 1225 & 0 & $27 \%$ \\
\hline
\end{tabular}

Notes: The table reports the survival rate estimates of firms based on non-parametric Kaplan-Meier survival estimate. The number of firms established in 1997 is 4617 . Year 15 (2012) is the last year of our dataset, so we cannot determine the number of exit in this year (because it is right-censored). KIBS firms include those firms, which are classified as codes 72-74 by the two-digit NACE (rev. 1.1) classification. 
Table 4: Coefficient Estimates of survival analysis for entrepreneurial firms, 1997-2012

\begin{tabular}{|c|c|c|c|c|c|c|c|c|}
\hline VARIABLES & (1) & (2) & (3) & (4) & (5) & (6) & (7) & (8) \\
\hline RelatedVariety & $\begin{array}{c}-0.160 * * * \\
(0.002)\end{array}$ & & & $\begin{array}{c}-0.119 * * * \\
(0.001)\end{array}$ & $\begin{array}{c}-0.174 * * * \\
(0.002)\end{array}$ & & & $\begin{array}{c}-0.127 * * * \\
(0.001)\end{array}$ \\
\hline UnrelatedVariety & & $\begin{array}{c}-0.106 * \\
(0.050)\end{array}$ & & $\begin{array}{c}-0.104 * \\
(0.058)\end{array}$ & & $\begin{array}{c}-0.116 * \\
(0.053)\end{array}$ & & $\begin{array}{c}-0.113^{*} \\
(0.062)\end{array}$ \\
\hline Specialization & & & $\begin{array}{c}0.015 \\
(0.109)\end{array}$ & $\begin{array}{l}-0.006 \\
(0.127)\end{array}$ & & & $\begin{array}{c}0.016 \\
(0.120)\end{array}$ & $\begin{array}{c}-0.017 \\
(0.141)\end{array}$ \\
\hline RegionSize & & & & $\begin{array}{l}-0.002 \\
(0.006)\end{array}$ & & & & $\begin{array}{c}-0.003 \\
(0.007)\end{array}$ \\
\hline Age & & & & $\begin{array}{c}0.240 * * * \\
(0.013)\end{array}$ & & & & $\begin{array}{c}0.257 * * * \\
(0.014)\end{array}$ \\
\hline Gender & & & & $\begin{array}{c}0.018 * * * \\
(0.003)\end{array}$ & & & & $\begin{array}{c}0.019 * * * \\
(0.003)\end{array}$ \\
\hline Immigrant & & & & $\begin{array}{c}-0.113 * * * \\
(0.021)\end{array}$ & & & & $\begin{array}{c}-0.123 * * * \\
(0.023)\end{array}$ \\
\hline NrFirms & & & & $\begin{array}{c}0.121 * * * \\
(0.037)\end{array}$ & & & & $\begin{array}{c}0.128 * * * \\
(0.041)\end{array}$ \\
\hline HighlyEducated & & & & $\begin{array}{c}-0.114 * * * \\
(0.027)\end{array}$ & & & & $\begin{array}{c}-0.121 * * * \\
(0.029)\end{array}$ \\
\hline FirmSizeGrowth & & & & $\begin{array}{c}-0.150 \\
(0.140)\end{array}$ & & & & $\begin{array}{c}-0.167 \\
(0.158)\end{array}$ \\
\hline Spin-off & & & & $\begin{array}{l}-0.266^{*} \\
(0.148)\end{array}$ & & & & $\begin{array}{l}-0.277 * \\
(0.160)\end{array}$ \\
\hline Merger & & & & $\begin{array}{l}-0.183 \\
(0.142)\end{array}$ & & & & $\begin{array}{l}-0.197 \\
(0.152)\end{array}$ \\
\hline Observations & 4,617 & 4,617 & 4,617 & 4,617 & 4,617 & 4,617 & 4,617 & 4,617 \\
\hline Loglikelihood & -26792 & -26791 & -26794 & -26790 & -6495 & -6494 & -6497 & -6492 \\
\hline
\end{tabular}

Notes: The table reports the coefficient estimates with clustered standard errors over 72 functional regions in the parentheses. Models (1) to (4) are based on Semi-Parametric Cox Proportional Hazard model. Model (5) to (8) are based on Parametric Survival Models with Weibull survival distribution. In all models, a negative coefficient means a negative effect on hazard and hence a positive effect on survival of the entrepreneurial firms. Significance level: * $p<0.05$, ** $p<0.01, * * * p<0.001$. 


\section{Appendix}

Table A1: Number of founded self-employed KIBS firms across Swedish functional regions in 1997

\begin{tabular}{|c|c|c|c|c|c|}
\hline Region \# & Region name & \# KIBS & Region \# & Region name & \# KIBS \\
\hline 1 & Stockholm & 1319 & 37 & Västerås & 111 \\
\hline 2 & Nyköping & 32 & 38 & Fagersta & 16 \\
\hline 3 & Eskilstuna & 73 & 39 & Vansbro & 7 \\
\hline 4 & Linköping & 191 & 40 & Malung & 6 \\
\hline 5 & Värnamo & 33 & 41 & Mora & 35 \\
\hline 6 & Jönköping & 105 & 42 & Falun & 78 \\
\hline 7 & Vetlanda & 11 & 43 & Avesta & 19 \\
\hline 8 & Tranås & 12 & 44 & Ludvika & 27 \\
\hline 9 & Älmhult & 15 & 45 & Gävle & 75 \\
\hline 10 & Ljungby & 16 & 46 & Söderhamn & 28 \\
\hline 11 & Växjö & 57 & 47 & Hudiksvall & 31 \\
\hline 12 & Kalmar & 51 & 48 & Ljusdal & 16 \\
\hline 13 & Vimmerby & 7 & 49 & Sundsvall & 81 \\
\hline 14 & Västervik & 15 & 50 & Kramfors & 20 \\
\hline 15 & Oskarshamn & 22 & 51 & Sollefteå & 6 \\
\hline 16 & Gotland & 28 & 52 & Örnsköldsvik & 16 \\
\hline 17 & Karlskrona & 55 & 53 & Östersund & 52 \\
\hline 18 & Kristianstad & 75 & 54 & Härjedalen & 7 \\
\hline 19 & Malmö & 525 & 55 & Storuman & 5 \\
\hline 20 & Halmstad & 87 & 56 & Lycksele & 14 \\
\hline 21 & Göteborg & 502 & 57 & Dorotea & 1 \\
\hline 22 & Borås & 83 & 58 & Vilhelmina & 3 \\
\hline 23 & Trollhättan & 90 & 59 & Åsele & 2 \\
\hline 24 & Lidköping & 33 & 60 & Sorsele & 4 \\
\hline 25 & Skövde & 72 & 61 & Umeå & 59 \\
\hline 26 & Strömstad & 16 & 62 & Skellefteå & 25 \\
\hline 27 & Bengtsfors & 5 & 63 & Arvidsjaur & 3 \\
\hline 28 & Årjäng & 6 & 64 & Arjeplog & 2 \\
\hline 29 & Eda & 3 & 65 & Luleå & 74 \\
\hline 30 & Karlstad & 109 & 66 & Överkalix & 2 \\
\hline 31 & Torsby & 8 & 67 & Övertorneå & 5 \\
\hline 32 & Hagfors & 3 & 68 & Haparanda & 5 \\
\hline 33 & Filipstad & 7 & 69 & Pajala & 2 \\
\hline 34 & Örebro & 131 & 70 & Jokkmokk & 3 \\
\hline 35 & Hällefors & 4 & 71 & Gällivare & 8 \\
\hline \multirow[t]{2}{*}{36} & Karlskoga & 20 & 72 & Kiruna & 13 \\
\hline & & & Total & & 4682 \\
\hline
\end{tabular}


Table A2: Descriptive statistics

\begin{tabular}{|c|c|c|c|c|c|}
\hline & Observations & Mean & S.D. & Min. & Max. \\
\hline RelatedVariety & 4617 & 3.10 & 0.34 & 0.18 & 3.41 \\
\hline UnrelatedVariety & 4617 & 0.92 & 0.23 & 1.73 & 4.84 \\
\hline Specialization & 4617 & 1.02 & 0.19 & 0.02 & 3.25 \\
\hline RegionSize & 4617 & 10.13 & 2.16 & 2.71 & 12.26 \\
\hline Age & 4617 & 44.13 & 12.09 & 16 & 83 \\
\hline Gender & 4617 & 0.31 & 0.46 & 0 & 1 \\
\hline Immigrant & 4617 & 0.16 & 0.36 & 0 & 1 \\
\hline NrFirms & 4617 & 2.42 & 1.53 & 1 & 10 \\
\hline HighlyEducated & 4617 & 0.51 & 0.50 & 0 & 1 \\
\hline FirmSizeGrowth & 4617 & 0.04 & 0.18 & -0.86 & 4.17 \\
\hline Spin-off & 4617 & 0.01 & 0.12 & 0 & 1 \\
\hline Merger & 4617 & 0.01 & 0.11 & 0 & 1 \\
\hline
\end{tabular}

